\title{
Construção de subjetividades no teatro: uma análise antropológica *
}

\section{Andrea Rangel Ribeiro**}

Resumo: Este artigo analisa algumas formas de construção de subjetividades em uma escola de teatro. Questôes como a qualificação de alguns como "talentosos", o hedonismo da profissão e a proposta pedagógica de desconstrução corporal são analisadas a partir dos relatos de campo. Ao final, é desenvolvida uma leitura dessas vivências a partir da ideia de um cuidado de si e do conceito de romantismo.

Palavras-chave: teatro; escola de teatro; subjetividade; desconstrução.

Construction of subjectivities in the theatre: an anthropological analysis.

Abstract: This article analyses some of the ways subjectivities are constructed at a theatre school. The qualification of some students as "talented", the hedonism of the profession and the proposal of body deconstruction are analysed through the fieldwork. At the end, an interpretation of these experiences through the idea of self-care and the concept of romanticism is developed.

Keywords: theatre; theatre school; subjectivity; deconstruction.

\section{INTRODUÇÃO}

Primeira aula do professor de teatro Andrei ${ }^{1}$. Quando entrei na sala de aula, o ambiente estava quase escuro, tocava uma música de origem indígena, bem alta, e havia

\footnotetext{
* Recebido em 22 de junho de 2008. Aprovado para publicação em 26 de maio de 2009.*

" Andrea Rangel Ribeiro é mestre em Ciência Política pelo Iuperj-TEC (2001) e doutora em Antropologia Social pela Universidade Federal do Rio de Janeiro (2008).

${ }_{1}$ Esta pesquisa faz parte da tese de doutorado em Antropologia Social defendida no Museu Nacional (UFRJ) em 2008. Todos os nomes próprios aqui mencionados sáo fictícios, com exceção daqueles marcados pela categoria fama como forma de reconhecimento social.
} 
poucos alunos. O professor, sentado em um banquinho, segurava dois pequenos tocos de madeira, um em cada mão. Ele estava calado e parecia muito sério e concentrado. Após a entrada de todos os alunos, Andrei desligou o aparelho de som e iniciou seu discurso de forma austera:

Há apenas dois tipos de homem no mundo: o homem-cidadão e o homem-poeta. Qual deles interessa ao teatro? $\mathrm{O}$ corpo do homem cidadão não interessa em nada ao teatro. $\mathrm{O}$ pudor, a razão e a falta de "energia" são coisas do homem cidadão. Isso não serve para nada! Não serve para a gente aqui. O que interessa ao teatro é o homem poeta, o homem artista. O homem poeta é o ator, que é esquizofrênico, intuitivo e faz mesmo. Há coisas que só o ator pode sentir e fazer. $\mathrm{O}$ ator é um animal primitivo, que tem em seu DNA a visceralidade de milhões de anos de história [...] Não é para qualquer um, não. É para quem pode. O palco é um lugar sagrado que reconhece de cara quem tem talento e pode pisar nele!

A ideia, explicitada por Andrei, de uma distinção clara entre dois tipos de homem na sociedade foi recorrente em meu trabalho de campo com alunos e atores de teatro. $\mathrm{O}$ homem convencional e obediente às normas sociais seria aquele que Andrei chamou de cidadão. $\mathrm{O}$ cidadão seria aparentemente racional, burguês e, por consequência, desinteressante. O homem artista, ao contrário, seria supostamente criativo, sensível e livre. De acordo com os alunos e professores de teatro com quem conversei, seria justamente esse $o$ ator de teatro.

Recordo-me de ter ouvido repetidas vezes discursos sobre o status diferenciado do ator, especificamente de teatro, desde meu ingresso nesse universo. Comecei a fazer teatro antes do curso de doutorado em Antropologia Social e sem qualquer pretensão etnográfica. No entanto, tal aproximação despertou em mim curiosidades, que se transformaram em um interesse posterior de pesquisa.

Uma das questôes que mais me inquietavam desde o início desse contato diz respeito ao significado da categoria "talento", e de seus equivalentes nesse grupo social. Tal categoria parecia distinguir os indivíduos considerados talentosos como pessoas especiais devido a sua "criatividade" e "sensibilidade". Essa inquietação inicial se transformou posteriormente em uma das questóes centrais de minha pesquisa de doutorado.

Escolhi investigar o universo dos estudantes de teatro. Para realizar a pesquisa de campo, me inscrevi como aluna em uma escola profissionalizante privada, localizada na Zona Sul da cidade do Rio de Janeiro. O objetivo da inserção na instituição como aluna foi realizar uma etnografia daquele ambiente social e, mais especificamente, da turma na qual estive matriculada: a turma A.

A instituição em questão é a Escola de Teatro Cacilda Becker (ETCB). O curso profissional de formação de atores da ETCB tem a duração de aproximadamente três anos. Os alunos têm aulas de segunda a sexta-feira, durante quatro horas por dia. $\mathrm{Na}$ escola são oferecidas várias disciplinas a cada semestre do curso. As mais frequentes são interpretação, corpo, voz, improvisação, música, história e teoria teatral. Apenas as duas 
últimas são disciplinas teóricas e representam aproximadamente um quarto do conteúdo programático de todo o curso. A mensalidade do curso profissional custava, no primeiro semestre de 2009, R\$ 655,00.

Nos primeiros cinco semestres, além das aulas práticas e teóricas, há apresentaçôes de algumas peças de teatro na própria escola. $\mathrm{O}$ público das peças é composto majoritariamente por alunos de outras turmas, além de amigos e familiares dos integrantes dos elencos. Após essa etapa de formaçáo, que dura cinco semestres, cada turma participa da montagem de um espetáculo profissional, que é exibida em algum teatro do circuito comercial da cidade. Após a conclusão do processo pedagógico, o aluno formado está apto a adquirir a carteira profissional de ator, também chamada de $\mathrm{DRT}^{2}$.

O trabalho de campo desta pesquisa ocorreu durante os três primeiros semestres de curso. Minhas observaçóes tiveram como foco o início do processo de aprendizagem e formação profissional da turma $\mathrm{A}$. O número de estudantes oscilou entre desesseis e vinte ao longo desse período. A faixa etária das pessoas variou entre 18 e 46 anos de idade. A maioria dos alunos mora na Zona Sul da cidade e possui padrão de consumo de classe média. Na turma havia certa proporcionalidade entre o número de homens e mulheres, fato incomum na escola, cuja predominância é feminina.

Desde o início do curso descobri, por meio de conversas informais, que a maioria dos vinte alunos preferia a carreira teatral à televisiva. A preferência pelo trabalho teatral ou televisivo parece ter um significado social relevante na Escola de Teatro Cacilda Becker. Tive a impressão de que as características sociais dos indivíduos que afirmavam preferir TV eram distintas dos traços mais marcantes daqueles que preferiam o teatro. A partir da percepçáo dessa diferenciaçáo na turma, optei por centrar a análise no grupo de pessoas que afirmavam preferir o último.

O grupo social analisado nesta pesquisa é composto pelos indivíduos da turma A, que declararam sua preferência pelo trabalho teatral. Na escola, meu contato foi mais próximo com aqueles que declaravam preferir o trabalho teatral e que faziam críticas constantes ao ator de televisão. Na turma A prevalecia esse perfil de aluno, assim como no turno da noite, no qual eu estive matriculada. À noite, os alunos são mais velhos que aqueles que cursam os turnos da tarde e da manhã e muitos têm uma segunda profissão. Vários informantes me disseram que não pretendiam ganhar dinheiro com aquilo, mas realizar um sonho pessoal ou romper com os padróes estéticos hegemônicos do teatro comercial e da televisão. A atuação televisiva para muitos desses analisados era tida como uma forma de ganhar dinheiro aquém de um trabalho artístico considerado como "verdadeiro". Pelas razóes expostas e por meus interesses enquanto pesquisadora, minha inserção no campo

\footnotetext{
${ }^{2} \mathrm{O}$ curso profissionalizante confere ao aluno o registro profissional como ator, ou seja, o DRT (registro na Delegacia Regional do Trabalho), através do Sindicato dos Artistas. O DRT não é obtido apenas através de escolas profissionais de teatro, mas também por meio da comprovação de experiência de trabalho no teatro, na TV ou no cinema. Alguns alunos da ETCB, por exemplo, já possuíam DRT devido a sua experiência profissional anterior ao ingresso na escola.
} 
buscava compreender os sentidos sociais das relaçóes construídas entre esses alunos que privilegiavam a carreira teatral em detrimento da televisiva.

\section{A ATUAÇÃO NO COTIDIANO DA ESCOLA E A QUALIFICAÇÃO COMO "TALENTOSO"}

"Aproveite ao máximo enquanto estiver estudando na escola para atuar e participar de tudo mesmo. Depois da formatura, você quase não vai ter chance de fazer teatro." Esse foi o conselho que recebi de um ator formado pela ETCB. Sua declaração me despertou para a relevância da "prática teatral" na escola de teatro. A importância de atuar, mesmo que no âmbito escolar, me pareceu fundamental para os analisados nesta etnografia. A preocupação com a prática teatral e com "estar em cena", mesmo que seja dentro de uma sala de aula, parece ser um valor fundamental para os estudantes de teatro analisados. A escola náo simboliza para seus alunos e professores apenas um local de formação profissional, mas também um espaço que estimula o exercício da atividade de atuar.

Os alunos já são chamados de atores pelos próprios professores desde que ingressam na escola. No campo, há certa indefinição do que é "ser ator". As pessoas são chamadas de "ator" ou de "aluno", por si mesmas e pelos outros, de forma aparentemente indiscriminada.

Há na escola alguns estudantes que já possuem registro profissional e que não se consideram atores. Essas pessoas afirmavam não se sentirem preparadas para o mercado de trabalho. Por outro lado, outros alunos sem DRT se autodenominam e são reconhecidos socialmente como atores, se referindo às suas performances em sala de aula como "trabalho de ator"'.

As apresentaçôes de peças na escola são consideradas pelos estudantes como parte de sua experiência profissional. Muitos ex-alunos e pessoas de fora da escola assistem às apresentaçóes desses espetáculos. Há vários boatos sobre espectadores influentes que oferecem propostas de trabalho para alguns participantes dessas apresentaçôes. A expectativa e a preocupação dos alunos quanto à exibição de suas peças é intensa, chegando inclusive a gerar diversos conflitos.

Entretanto, a preocupação dos alunos náo se restringe às apresentaçóes de peças na escola, mas também diz respeito às apresentaçôes de trabalhos para os professores durante as aulas. Nas aulas práticas, os alunos devem apresentar ocasionalmente pequenas cenas teatrais ou performances, que são avaliadas pelos professores.

As performances podem ser de diversos tipos. As aulas de interpretação geralmente trabalham com cenas de peças teatrais. A professora Fátima, por exemplo, exige de todos

\footnotetext{
${ }^{3}$ O termo "performance", nesta pesquisa, significa atuação ou espetáculo no qual o artista fala e age por conta própria.
} 
os alunos a apresentaçáo para a turma de, no mínimo, uma cena por semana. Ao longo do semestre, duas cenas são avaliadas como provas.

Já o professor Henrique trabalha bastante com cenas criadas pelos estudantes a partir de algumas regras pré-estabelecidas por ele a cada aula. A criação coletiva ou individual de cenas no teatro é chamada de improvisação. Após alguns meses de improvisos, há a execução da uma cena por todos os alunos da turma. No caso etnografado, a cena apresentada como prova no último dia de aula foi da peça $U m$ bonde chamado desejo ( $A$ Streetcar Named Desire) de Tennessee Williams.

As aulas de literatura dramática e história do teatro, em alguns momentos, trabalham com leituras dramatizadas e cenas teatrais elaboradas pelos alunos. As disciplinas chamadas de voz e de corpo também trabalham ocasionalmente com cenas de peças. Outras formas de performances frequentes se referem a exercícios e jogos teatrais, considerados como preparatórios para as cenas e importantes para a formaçáo do ator. Nas aulas de corpo, por exemplo, são requisitadas performances nas quais o aluno é impedido de falar, deve evitar usar movimentos e posturas considerados cotidianos e, ainda assim, comunicar algo que seria supostamente perceptível para a "plateia" composta pelos colegas de turma e pelo professor em sala de aula.

Alguns exercícios são solicitados num momento imediatamente anterior a sua própria execução, enquanto outros são requisitados com antecedência. Nesses últimos, os alunos costumam ensaiar e preparar uma espécie de mini espetáculo com música, figurino, cenário e mudança na iluminaçáo da sala. A escola estimula a reproduçáa da atmosfera do ambiente profissional. As aulas ocorrem normalmente em salas de aula grandes, com poucos móveis e muitas lâmpadas, o que torna mais fácil a criação do ambiente teatral.

Durante cada performance a atenção do professor e dos colegas de turma é capturada. Nota-se frequentemente que isso causa uma aparente satisfação nos alunos em estarem sendo assistidos por eles. Após a execução do que foi proposto em aula, cada um é analisado naquilo que teria sido supostamente bem-sucedido e no que teria fracassado. Essa atenção individualizada é aparentemente o momento de tensão esperado por todos, ou pela grande maioria. O simples fato de ser visto e analisado em um exercício é, para esses alunos, uma forma de reconhecimento social especial.

A seriedade ritualística das apresentaçóes em aula é notória. Cada uma representa um momento importante no curso. Todos os presentes compóem uma pequena plateia, silenciosa e atenta a cada movimento de quem está "em cena". Após a execuçáo da performance, o professor faz comentários. Às vezes os alunos que assistiram também discutem a respeito do que foi exibido.

Alguns estudantes reagem com grande decepção quando criticados pelo professor após sua performance. Às vezes eu mesma estranhava a reação de pessoas que recebiam uma pequena crítica e ficavam cabisbaixos por um longo tempo (alguns com uma expressão de choro). Os colegas de turma nem notavam ou buscavam encarar com naturalidade tal reação. Esse comportamento parecia de alguma forma coerente com aquele lugar. 
A importância conferida a essas performances curtas talvez esteja relacionada à oportunidade de aproveitar um ambiente aberto à singularidade dos alunos. Cada apresentação tem aparentemente o potencial de destacá-los como "talentosos" ou pessoas especiais e criativas, mesmo que seja por um curto prazo. Categorias como "talentoso", "sensível", "criativo", "bom ator" e "orgânico" são algumas das que conferem aos indivíduos um status diferenciado na sua turma e até na escola.

É comum o professor eleger uma performance como a mais próxima daquilo que foi pedido aos alunos em cada aula. Quando alguém é muito elogiado, a sensação dos outros é de aparente desapontamento. Os alunos parecem se preocupar com essa espécie de hierarquia criada a cada exercício em sala de aula, criando entre os estudantes uma espécie de competição pelo maior elogio a cada performance.

A competitividade é perceptível de forma explícita e implícita em diversas ocasiôes e entre praticamente todos os observados. A competiçáo entre os alunos de teatro ocorre em distintos níveis e por propósitos diferenciados, mas a busca por ser o mais admirado na turma é um grande estímulo à competitividade nesse ambiente. Essa questão nos remete à importância de ser considerado "talentoso" e ao status diferenciado que essa categoria confere aos alunos na escola de teatro.

A expectativa e o esforço observados na execução das cenas durante as aulas parecem estar relacionados a essa busca por se diferenciar. A opinião dos professores é bastante importante para a construção da imagem dos alunos como "atores" nesse sentido. Quando um indivíduo é muito elogiado, seu prestígio muda na turma. Suas apresentaçóes passam a ser analisadas com mais atenção pelos colegas. Alguns parecem tentar copiá-lo, outros o admiram e há aqueles que torcem por uma mudança na sua situação de prestígio social. Essa mudança de status acontece quando os professores passam a criticar o mesmo aluno que foi muitas vezes congratulado. Alguns casos interessantes foram analisados nesse sentido.

A suposta habilidade de atuar "de verdade" parecia ser própria a poucos indivíduos. Na turma A, três alunos são qualificados como talentosos com maior frequência por professores e colegas: Natasha, Marcelo e Maria. Parecia haver uma competitividade intensa entre eles na busca da qualificação como o mais talentoso a cada apresentação das peças na escola e de trabalhos em sala de aula. $\mathrm{Na}$ apresentação de Sonho de uma noite de verão, de William Shakespeare, os três fizeram o mesmo personagem: Puck. Cada ator fazia o Puck em três sessôes da peça. Os comentários comparativos das interpretaçôes dos três atores eram constantes entre seus colegas. Não havia uma unanimidade no julgamento a esse respeito, mas, de forma geral, afirmavam gostar mais do Puck de Marcelo e em segundo lugar do de Natasha. A atuaçáo de Maria foi considerada "fraca" por muitos colegas e aquém de sua suposta capacidade de atriz.

Os critérios de qualificação de alguém como talentoso parecem pouco objetivos e de difícil definição no meio teatral. O discurso dos professores sobre as apresentaçóes e o talento dos alunos influenciava a opiniáo de meus colegas sobre o assunto. A qualificação como talentoso tampouco me pareceu rígida e fixa, pois no início do trabalho de 
campo Natasha era a atriz mais admirada. Depois esse lugar de destaque se tornou um palco de disputa entre outros alunos, como Marcelo e Maria.

O critério da verdade da atuação é aparentemente utilizado como uma espécie de hierarquia construída localmente que define quem seria especial em contraposiçáo a quem seria comum no métier teatral. Esse critério é construído socialmente a partir de uma série de discursos, como o dos professores e dos colegas de turma, que qualificam os indivíduos na escola de acordo com o que pensam sobre suas supostas habilidades.

\section{HEDONISMO E SACRALIDADE: SIGNIFICADOS DE ATUAR}

A busca pelo reconhecimento social como talentoso é um dos fatores que parece estimular a competitividade entre os atores de teatro observados. As disputas travadas entre os alunos nessa busca podem adquirir uma conotação violenta. Agressóes verbais e físicas, fofocas e conflitos de diferentes naturezas surgiram em função de questóes que eu, particularmente, considerava de pouca relevância. A conquista do personagem protagonista, ou a busca por um maior número de falas ou por um maior destaque em cada cena de um espetáculo podiam gerar situaçóes de conflito consideradas grave por meus analisados.

Entretanto, esse contexto é permeado por um imaginário coletivo idílico sobre o fazer teatral. Estar em cena é considerado como um momento mágico e único. O preço a ser pago é altíssimo, dizem muitos. Mas todo sacrifício em prol do teatro seria recompensado por essa magia de estar em cena, de acordo com alguns informantes. $O$ professor da escola e diretor teatral Bertolo Maciel disse algo interessante a esse respeito:

O teatro é para quem não pode viver sem ele. Náo pode respirar sem ele. [...] É um vício mesmo! [...] É como um baú que você tem que carregar. [...] Sabe aquele amante que te maltrata, rouba seu dinheiro, te chifra, dá na tua cara e te esculhamba? Ele acaba contigo, mas quando vai te fazer uma visitinha você diz: querido, entra, vamos tomar um cafezinho? Esse cara é o teatro.

Apesar de todos esses contratempos da carreira profissional e da vida escolar, a escolha pelo teatro é considerada por muitos informantes da ETCB como uma das formas mais plenas de prazer e de felicidade.

O ator de teatro Sérgio Britto, em uma palestra na escola, afirmou que o grande amor da sua vida é o teatro. E ainda enfatizou que nenhum orgasmo é comparável ao "orgasmo cênico": a sua maior fonte de prazer seria estar em cena.

Outro ator de teatro e professor da escola, Fernando Bonfim, afirmou que só se sentia feliz e bem consigo mesmo se estivesse fazendo teatro. $\mathrm{O}$ teatro, prossegue Fernando, é encantador, mágico e lida com energias vitais para os seres humanos. Seria assim um privilégio para quem o pratica. Ele ainda definiu sua arte como uma infinita fonte de felicidade. 
A ideia de que "o palco é sagrado"^ é explicitada por outras pessoas no campo analisado, além de Fernando Bonfim e Sérgio Britto. Muitos acreditam em uma característica mística e mágica de seu ofício. As ideias de felicidade e de prazer estáo intimamente ligadas a esse sentido místico que o teatro parece ter para muitos atores. A suposta magia de estar em cena parece proporcionar aos intérpretes sensaçóes que eles denominam como prazer, felicidade, excitaçáo e emoçáo, dentre outras. Assim, o simples ato de representar teria aparentemente algo de espiritual e de sublime para eles.

Gilberto Icle (2006, p.58), ator e professor de teatro, estabelece uma analogia entre o trabalho do ator e a experiência de um xamá. Icle afirma que o ator transcende seu corpo e sua mente para alcançar, com todo o seu ser, a plateia. Nessa transcendência, o ator estaria lidando com sua própria totalidade, referente ao que Icle chama de condição natural da humanidade. De acordo com o autor, é o entregar-se a si mesmo que possibilita ao intérprete um poder especial de chamar a atençáo do público.

Margot Berthold (2000, p.2) também compara o ator a um xamá. A autora declara que o teatro pressupóe a elevação do artista acima das leis que governam a vida cotidiana. O teatro é definido por ela como um verdadeiro encanto mágico, e o ator como alguém que obedece ao comando da conjuraçáo de uma realidade mais verdadeira e se transforma no mediador de um descortino mais elevado 5 .

A relação do teatro com a magia e a religiáo também é enfatizada pelos principais teatrólogos contemporâneos. $\mathrm{O}$ mito da origem religiosa do teatro é recorrente não apenas na escola observada, mas na literatura teatral tradicional. De acordo com essa versão, a origem do teatro no Ocidente estaria nos rituais dionisíacos gregos. $\mathrm{O}$ teatro teria surgido na Grécia antiga, a partir dos sagrados festivais rurais em homenagem ao deus Dionísio. A crença de que Dionísio teria se tornado o deus do teatro quando os ritos dionisíacos se desenvolveram e resultaram na tragédia e na comédia, é amplamente difundida não apenas na escola, mas no teatro ocidental contemporâneo.

No teatro há variadas combinações entre arte e religiosidade. Homem artista, bom ator, alguém especial, talentoso, xamã e sacerdote são alguns dos termos que designam status de superioridade para os intérpretes teatrais. Esse status tem um valor sagrado para aqueles que o almejam.

De acordo com Duarte (2006, p.10), o religioso nas sociedades modernas não deve ser compreendido a partir de uma perspectiva nominalista linear, mas no sentido amplo de uma visão de mundo, ou seja, uma cosmologia estruturante na qual se reconhece que o espaço do religioso abarca hoje muitos valores e comportamentos laicos e não-confessionais.

\footnotetext{
${ }^{4}$ Relembramos aqui a citação do discurso do professor Andrei.

5 Assim como Icle, Berthold é considerada nesta pesquisa como uma autora que expressa perspectivas análogas à ideologia nativa expressa nos professores e alunos da ETCB, que conferem um caráter sagrado ao ato de interpretar.
} 


\section{A "DESCONSTRUÇÃO CORPORAL" COMO MÉTODO DE PREPARAÇÃO DE ATORES E A VIA NEGATIVA TEATRAL}

No trabalho de campo, quase todos os observados pareciam desejar ser qualificados pelos colegas como atores talentosos. Apesar do caráter hedonista desse destaque, alcançá-lo parece exigir muito esforço e sacrifício. O curso profissionalizante de teatro é considerado apenas como um dos meios de aprimoramento do ator na construção de sua carreira e na sua suposta busca por ser reconhecido como alguém "especial".

Maria Claudia Coelho (1989, p.40) discute a imagem da profissão de ator para os estudantes de teatro. Um dos aspectos levantados pela antropóloga, que se revelou pertinente em minha observação participante, é o do privilégio do corporal e do sensorial, em detrimento do racional, no discurso e nas aulas de teatro. Nas aulas práticas há diversos exercícios de sensorialização voltados para uma espécie de refinamento e domínio da percepçáo corporal. A ideia de autoconhecimento, assim como de domínio emocional e corporal são consideradas fundamentais para o trabalho de atuação ${ }^{6}$.

As práticas teatrais observadas nas aulas trabalham com propostas corporais que visam supostamente a bloquear o pensamento racional dos alunos. Essas propostas pedagógicas são chamadas pelos teóricos de teatro, e por alguns professores, de "desconstrução" ou "reconstrução corporal". Na escola, esse processo é visto como essencial para a preparaçấo dos atores de teatro.

Podemos estabelecer aqui um paralelo com a antropologia da performance de Richard Schechner (1995, p.208) no que diz respeito ao "comportamento restaurado". Trata-se, para o autor, de um modelo de comportamento que instrui o performer sobre como deveria desempenhar seu papel ${ }^{7}$. No caso do teatro, o comportamento restaurado é o processo de aprimoramento das habilidades estéticas dos atores por meio da desconstrução corporal.

Schechner, seguindo a teoria dos rituais de Arnold van Gennep, declara que a restauração tende a ocorrer na "fase preliminar" da performance, ou seja, durante ensaios, oficinas e também cursos teatrais. Rubens Silva (2005. p.37), ao comentar Schechner, descreve o comportamento restaurado como um trabalho árduo, intenso e rigoroso, que vai além do esforço físico e intelectual, mas também traz à tona experiências internalizadas pelos indivíduos ao longo de seu processo de socialização.

As práticas de reconstrução corporal observadas nas aulas de teatro propóem um aprendizado de novos movimentos, gestos e posturas. A busca pelo aprimoramento da arte de representar é a justificativa de atores, diretores e professores para a opçáo por

${ }^{6}$ No curso analisado, a maior parte das disciplinas oferecidas são práticas e baseadas em um trabalho predominantemente corporal. Há poucas disciplinas teóricas ao longo dos cinco semestres de curso.

7 Schechner é um dos teóricos da antropologia da performance. A definição de performance apresenta algumas oscilaçôes entre seus diferentes autores. Richard Schechner trata das performances como situaçôes sociais dentre os acontecimentos extracotidianos que constituem um espaço simbólico de representação da realidade social.

${ }^{8}$ Aspas do autor. 
uma formaçáo profissional em uma escola de teatro. Trata-se de uma nova aprendizagem dos "usos do corpo", de acordo com o sentido da expressão usada por Marcel Mauss (1974, p.14). De acordo com Mauss, os fatores culturais predominariam na arte de utilizar o corpo humano. Assim, gestos, posturas e movimentos corporais estáo para além do domínio biológico e seriam modelos culturais resultantes de um longo processo de aprendizagem, que varia de sociedade para sociedade.

O trabalho de Jane Russo (1993, p.42) sobre as terapias corporais no Rio de Janeiro nos anos 1990 possibilita uma leitura específica dessa questáo da "desconstrução" no teatro. A autora descreve um contexto de cultura alternativa, resultante do movimento da contracultura dos anos 1960, que critica o dualismo corpo/mente e razão/emoção dominante no pensamento científico produzido pelas sociedades industriais. As práticas alternativas não teriam fronteiras determinadas e entrecruzariam saberes separados na modernidade, como o terapêutico e o religioso. As técnicas corporais fariam parte desse complexo alternativo. Uma das técnicas narradas por Russo inclusive se chama "expressáo corporal - uma prática em teatro".

Wilhelm Reich seria, segundo a autora, uma referência-chave para a maioria das terapias corporais que valorizam noçóes como consciência corporal, espontaneidade e repressão. A técnica corporal criada por Reich serviu de referência, diz a autora, para o desenvolvimento de terapias corporais náo reichianas. Alguns pontos básicos de Reich marcam essas novas abordagens do corpo, tais como a crença em que a chave para os males psíquicos está no corpo, a necessidade de liberaçáo do corpo (e da pessoa através dele), a oposiçáo entre o natural e o social e a ideia de energia.

Todas essas noçóes fazem parte do vocabulário básico docente das artes dramáticas. O corpo é o instrumento de trabalho do ator, diz-se frequentemente. Através do autoconhecimento e do domínio corporal, o intérprete poderia criar qualquer personagem, de acordo com os valores nativos. A ideia de "libertaçáo do corpo" propóe romper com os movimentos cotidianos e conhecidos dos alunos. A ideia da desconstrução visa justamente libertar o indivíduo e seu corpo das supostas repressóes sociais, consideradas opressoras.

A ideia de libertação estaria intrinsecamente relacionada à de natureza, pois o homem qualificado como natural e instintivo seria supostamente a matéria-prima do trabalho do ator. $\mathrm{O}$ ator deve, de acordo com essa ideologia, se libertar do que é construído socialmente para encontrar sua própria natureza. Desse encontro surgiria um trabalho artístico dito verdadeiro ou, de acordo com Stanislavski, "orgânico". Icle (2006, p.80) trata especificamente do assunto, abordando um suposto encontro do ator com a sua totalidade e com sua própria natureza humana ao atuar.

A formação do ator é entendida como a reconstrução de um novo corpo com habilidades expressivas específicas. $\mathrm{O}$ discurso vigente é o da necessidade do domínio corporal e da integração do corpo com a mente para a realização de uma boa atuação. O papel da escola seria assim, declaradamente, o de trabalhar com o aprimoramento dos corpos dos atores nessa direção. 
Segundo Nunes (1998, p.22), o método de preparação de atores teórico e racional, típico do século XIX, é denominado como via positiva. Essa via predominou no Ocidente até aproximadamente a primeira metade do século XX. A via negativa, em contraposição à primeira, estaria pautada na eliminação dos chamados bloqueios corporais e emocionais, que supostamente limitam a criação do ator. Tal caminho se inspiraria em filosofias orientais, como o budismo e o taoísmo. A preparação do ator pela via negativa consiste, para a autora, na busca de qualidades mais sensoriais e menos racionalistas para o seu trabalho.

De acordo com Icle (2006, p.9), Jacques Copeau instaurou um método pautado na eliminaçáo dos bloqueios do ator, a via negativa. Trata-se de identificar o que prejudica o trabalho criativo do ator e promover sua transformaçáo. Copeau teria tentado minimizar o que considerava processos racionais no trabalho do ator. Esse aspecto foi retomado por Grotowski que, em seu livro Em busca de um teatro pobre, utiliza o conceito de via negativa, relacionando aos procedimentos que supostamente tornaráo o ator o mais "autêntico" possível. Peter Brook também explora procedimentos de trabalho da via negativa e afirma que se trata de uma espécie de proposta de desconstruçáo do próprio ator.

A noçấo de via negativa surge na religião. Sua origem é latina e se refere à teologia negativa, segundo a qual, devemos transcender as palavras para compreender a origem da existência de Deus. O divino seria inefável e estaria para além da ideia humana de existência. Aos homens só seria possível tentar descrever Deus por aquilo que ele não é. A teologia negativa está presente, de diferentes formas, no cristianismo e no judaísmo, assim como no hinduísmo, no budismo, no taoísmo e em outras religióes orientais.

O discurso da via negativa é o da desconstrução momentânea daquilo que o ator supostamente seria socialmente. Essa desconstrução ocorreria por meio de diferentes tipos de exercícios e jogos teatrais, que o colocam em situaçóes emocionais e corporais consideradas limite, visando uma atuação supostamente menos racional e artificial. A proposta da via negativa pressupóe que alguns exercícios e jogos teatrais específicos poderiam desconstruir momentaneamente as supostas armaduras do indivíduo ocidental moderno, ou daquilo que o professor de teatro Andrei chama de homem-cidadão.

A via negativa e as propostas de "desconstrução corporal" podem ser interpretadas como projetos de resgate do que os atores acreditam ser uma espécie de natureza humana em sua essência. Pois, segundo essa via estética, a partir do encontro com tal natureza o ator se sentiria supostamente espontâneo e livre para criar seus personagens de forma pretensamente mais autêntica e convincente para o público?.

\section{CUIDADO DE SI E ROMANTISMO}

Na escola de teatro observada há uma valorização das práticas sociais que nos remetem às ideias de cuidado de si e de cultivo de uma interioridade e de uma intimidade

\footnotetext{
9 A categoria de natureza humana é constantemente empregada pelos nativos neste sentido.
} 
individual. O contexto das terapias alternativas e corporais tratado por Jane Russo (2001, p.117) dialoga com essas questôes. Segundo a autora, a proliferaçáo de cursos de yoga e tai-chi-chuan, o uso da medicina oriental, de florais de Bach, assim como a prática de diferentes estilos de terapia e de arte terapia estáo ligados a uma preocupaçáo contemporânea em romper com o rigor do comportamento racional e controlado.

Os atores de teatro compartilham dessa crença, que a autora qualifica como parte da cultura alternativa no Ocidente. Na ETCB, muitas aulas relembram esse quadro terapêutico traçado por Russo. Nas aulas de voz, o aluno aprende a cuidar do seu aparelho fonador para não danificá-lo com esforço e abuso vocal. Muitas aulas de interpretação são terapêuticas, fazendo uso de depoimentos íntimos dos alunos. As aulas de corpo visam "desbloqueá-lo" e "libertá-lo". O ator deve conhecer e saber como controlar seus movimentos e estímulos corporais no caminho de construçáo dos personagens. A proposta de desconstruçáo corporal também faz parte desse propósito de aprimoramento pessoal em prol do trabalho de atuação.

Essa questão do cuidado de si, aparentemente presente no campo, pode ser lida a partir do diálogo com o conceito de cultura subjetiva de Georg Simmel. Simmel (2005, p.578) ao abordar o processo de individualização, típico das cidades grandes, descreve dois tipos de indivíduos: o homem filisteu e o homem artista. O filisteu é aquele tomado pelo domínio do entendimento e da racionalidade, pelo desânimo e pela falta de criatividade. O homem artista se contrapóe a essa forma de comportamento e luta por sua particularização qualitativa na sociedade.

O filisteu faria parte daquilo que Simmel chama de cultura objetiva. O universalismo, correspondente ao individualismo quantitativo, refere-se à busca de uma medida comum para a mensuraçáo das coisas, de uma racionalização e de uma objetivaçáo. A cidade grande seria, segundo o autor, o local típico para o cultivo desses valores. O igualitarismo entre os indivíduos resultaria em sua massificação e indiferenciação. O domínio da economia monetária, do mercado e do espírito contábil é o ambiente do homem filisteu. Nessa cidade cosmopolita, também se cultuaria um comportamento indiferente e blasé no trato com os desconhecidos, em relação aos quais se mantém constante reserva e distância.

Anonimato, indiferenciação e solidão compóem o quadro desenhado por Simmel, que retrata o individualismo das sociedades capitalistas modernas nas cidades grandes. Entretanto, é justamente nesse contexto que os indivíduos teriam a liberdade de transformar sua condiçáo de anonimato e se destacar socialmente. $\mathrm{O}$ individualismo possibilitaria o desenvolvimento da autonomia necessária à sua singularização.

Simmel afirma que o caráter blasé garante ao indivíduo uma espécie e uma medida de liberdade pessoal. A reserva em relação aos outros é pré-condição para a produção de uma interioridade e de um cuidado de si, ou seja, de uma Bildung. Essas são características daquilo que Simmel chama de cultura subjetiva. O individualismo qualitativo, referente a essa cultura, diz respeito ao privilégio das emoçóes sobre o conhecimento racional. Para Simmel trata-se de uma valorizaçáo da sensibilidade e da expressividade em detrimento do anonimato correspondente ao individualismo quantitativo. 
A ideia de uma Bildung se atualiza na cidade grande, de acordo com o conceito de cultura subjetiva de Simmel. A singularização dos indivíduos pode ser construída por caminhos como o cultivo de si, a construção de uma interioridade e a criação de uma intimidade pessoal.

Keith Thomas (1988, p.11), ao abordar a mudança de atitudes em relaçáo às plantas e à jardinagem, na Inglaterra entre os séculos XVIII e XIX, também nos remete ao conceito de cultura subjetiva. Thomas descreve como o jardim passou a ser uma infinita fonte de satisfação pessoal, onde seu proprietário poderia encontrar um refúgio e renovar sua vitalidade. A possibilidade de autoexpressão individual por meio da liberdade de criaçáo explica porque a jardinagem se tornou uma obsessão inglesa. Tal como os bichos de estimação e as árvores, os jardins serviam para fortalecer o sentido de identidade de seus proprietários e aumentar sua autoestima.

A jardinagem, no caso descrito, nos remete de certa forma ao estatuto das atividades artísticas, a partir do romantismo na cultura ocidental. Desde o século XVIII, aproximadamente, as artes têm representado um papel relevante na construção social da pessoa no Ocidente ao possibilitarem uma autoexpressáo individual por meio da liberdade de criaçáo estética. O suposto desenvolvimento do que se convencionou chamar de "criatividade artística" (que no teatro nos remete à ideia de talento) parece ter se tornado uma fonte de satisfaçáo pessoal, de prazer e de felicidade para os indivíduos.

Todas essas características parecem ser importantes para a compreensão do ethos teatral. O privilégio das emoçôes, da subjetividade, da criatividade e de um cuidado de si é bastante significativo no meio artístico analisado. A busca de uma espécie de singularização social é percebida de diversas formas nos atores e estudantes de teatro.

A partir do romantismo, a arte é considerada como forma de expressão dos sentimentos individuais e como campo de atividades no qual o indivíduo poderia deixar sua marca na história. De acordo Norbert Elias (1995, p.60), a partir desse movimento, a qualidade de gênio teria surgido como uma forma de reconhecimento social para o artista.

$\mathrm{Na}$ arte, o romantismo valoriza o "culto ao eu". Essa questáo estaria relacionada à crença na singularidade do artista que consegue, pela imaginaçáo, penetrar num mundo abstrato e restrito a poucos. A regra suprema do romantismo é a inspiração individual. Como decorrência da "liberdade", da "espontaneidade" e do "individualismo", a arte teria se tornado sinônimo de autoexpressão.

De acordo com Duarte (2004, p.6), o romantismo promoveu uma valorização da sensibilidade, da sensorialidade e das emoçóes como reação ao racionalismo iluminista ao longo dos séculos XVIII e XIX. Esse movimento teve como uma de suas características principais uma concepçáo vitalista da natureza e do universo como um todo, em contraposição ao mecanicismo científico. Tal concepçáo de natureza, segundo o autor, se acopla a um monismo totalizante, em oposição ao modo fragmentário e analítico da visão mecanicista. 


\section{REFERÊNCIAS BIBLIOGRÁFICAS}

BERTHOLD, Margot. História mundial do teatro. Sáo Paulo: Perspectiva, 2000.

COELHO, Maria Claudia. Teatro e contracultura: um estudo de antropologia social. Dissertação (mestrado em Antropologia Social). Rio de Janeiro: PPGAS/Museu Nacional, Universidade Federal do Rio de Janeiro, 1989.

DUARTE, Luiz. "A pulsão romântica e as ciências humanas no ocidente". Revista Brasileira de Ciências. Sociais. São Paulo, vol. 19, n.5, jun. 2004, pp.5-19. (org.). Família e religiáo. Rio de Janeiro: Contracapa, 2006.

ELIAS, Norbert. Mozart: sociologia de um gênio. Rio de Janeiro: Jorge Zahar, 1995.

ICLE, Gilberto. O ator como xamã: configurações da consciência no sujeito extracotidiano. São Paulo: Perspectiva, 2006.

MAUSS, Marcel. "As técnicas corporais". In: Sociologia e antropologia. São Paulo: EPU/Edusp, vol. II, 1974.

NUNES, Sandra. O corpo que pensa: o treinamento corporal na formação do ator. Dissertação (mestrado em Comunicação e Semiótica). São Paulo: PUC, 1998.

RUSSO, Jane. "A pós-psicanálise - entre Prozac e florais de Bach". In: ___ (org.). Clio-Psyche hoje: fazeres e dizeres psi na história do Brasil. Rio de Janeiro: Relume-Dumará, 2001, pp.117-123.

SCHECHNER, Richard. "Restauração do comportamento". In: BARBA, Eugênio; SAVARESE, Nicola. A arte secreta do ator: dicionário de antropologia teatral. Campinas: Hucitec, 1995, pp.205-210.

SILVA, Rubens. "Entre 'artes' e 'ciências': a noção de performance e drama nas ciências sociais". Horizontes Antropológicos, Porto Alegre, ano 11, n. 24, 2005, pp.35-65.

SIMMEL, Georg. "As grandes cidades e a vida do espírito". Mana: estudos de antropologia social. Rio de Janeiro, 2005, v.11, n.2, pp.577-591.

THOMAS, Keith. O homem e o mundo natural: mudanças de atitude em relação às plantas e os animais (1500-1800). São Paulo: Companhia das Letras, 1988. 